\title{
Nie-stosow(a)ne analogie. Lesbos Renaty Lis jako narracja poszerzająca doświadczenie uchodźcze ${ }^{1}$
}

\author{
Inappropriate/Unapplied analogies. Lesbos by Renata \\ Lis as a narration that extends the exile experience
}

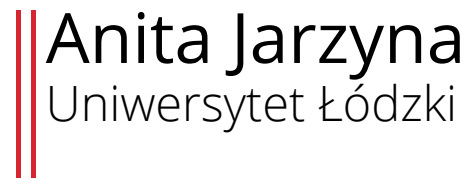

\begin{abstract}
Abstrakt: The study is mostly devoted to Renata Lis's book entitled Lesbos. The essays composing the book, about three writers who refer in their work to Sappho to tell about homosexual identity, are complemented by a narration about the position of today's refugees placed in the Lesbos camp. The sketch is an attempt to think of the opportunities brought by the poetry of essay, which allows us to extend our thought on the refugees' condition beyond the context of provisional problems and the language of publicity by confronting their experience with other forms of exclusion. The author invokes the existential meditation of Tadeusz Sławek, entitled U-chodzić, which is related by genre and raises similar issues, as well as the set of ornithological sketches by Stanisław Łubieński, entitled Dwanaście srok za ogon; in relation to the later work, the book shows that Lis's intention should be extended by a non-anthropocentric dimension. Then the idea of an open interpersonal community is more complete, being an idea of a community of genres.
\end{abstract}

Key words: refugees, animal studies, homosexual identity, essay

Streszczenie: Artykuł poświęcony jest przede wszystkim książce Renaty Lis pt. Lesbos. Składające się na nią eseje o trzech pisarkach odwołujących się w swojej twórczości do Safony, by opowiedzieć o tożsamości homoseksualnej, dopełnia narracja o sytuacji współczesnych uchodźców przebywających w obozie na wyspie Lesbos. Niniejszy szkic przynosi próbę namysłu nad możliwościami, jakie stwarza poetyka eseju, pozwalająca rozważyć kondycję uchodźców poza kontekstem doraźnych problemów, poza dominującym publicystycznym językiem, konfrontując to doświadczenie z innymi formami wykluczenia. Autorka artykułu przywołuje przy tym pokrewną gatunkowo i poruszającą podobne kwestie medytację egzystencjalną Tadeusza Sławka pt. U-chodzić oraz zbiór szkiców ornitologicznych Stanisława Łubieńskiego pt. Dwanaście srok za ogon, w związku z tą drugą książką pokazuje, iż zamysł Lis warto poszerzyć o wymiar nieantropocentryczny. Wówczas idea otwartej międzyludzkiej wspólnoty realizuje się pełniej jako idea wspólnoty międzygatunkowej.

Słowa kluczowe: uchodźcy, studia nad zwierzętami, tożsamość homoseksualna, poetyka eseju

${ }^{1}$ Artykuł powstał w ramach realizacji projektu „Post-koiné. Zwierzęta i poeci (studia wybranych przykładów w literaturze polskiej)”, sfinansowanego ze środków Narodowego Centrum Nauki, przyznanych na podstawie decyzji numer DEC-2014/12/S/HS2/00182. 
Wszyscy jesteśmy uchodźcami z brzuchów. Bez prawa stałego pobytu.

(Kuczyńska-Koschany 2006, 152)

\section{1.}

Nawoływania biegną w naszą stronę,

ale my głosu nie słyszymy -

noc milczy ponad morzem.

(Cyt. za: Lis 2017, 166)

Przytaczam wyimek z twórczości poetyckiej Safony, chcąc uczynić go drugim mottem, które jednak od razu wymaga paru słów wyjaśnienia.

Ten fragment przywołuje Renata Lis w eseju pod tytułem Lesbos, w środku opowieści o obozie dla uchodźców, mieszczącym się na wyspie, w mieście Moria. Ale słów starożytnej poetki autorka nie traktuje jako spełniającego się właśnie proroctwa, raczej uznaje je za niezwykle trwałą diagnozę, diagnozę tak ówczesnej sytuacji Europy - tej sprzed stuleci oraz tej sprzed dziesięcioleci - jak i jej współczesnej kondycji, wciąż niestabilnej.

Zarazem Lis-czytelniczka, gorąco sprzeciwiająca się dopisywaniu doraźnych tez do utworów literackich, nie opatruje przywołanego okruchu pieśni Safony komentarzem; cytując go w tym szczególnym kontekście, podtrzymuje ruch znaczeń i tajemnicę jego wymowy.

2.

Lesbos składa się z siedemdziesięciu czterech fragmentów zebranych w czterech częściach - każdą, choć Lis poprowadziła między nimi liczne przęsła, można by również czytać jako osobny esej. Pierwsze trzy poświęcone są twórczyniom (Sofii Parnok, Annie Kowalskiej i Jeanette Winterson), dla których ważnym punktem odniesienia - nie tylko stricte literackim, także szerzej tożsamościowym - stała się Safona; ostatni natomiast to nieledwie reportażowy zapis wyprawy na wyspę Lesbos. Centralne miejsce zajmuje w nim relacja z obrzeży obozu dla uchodźców w mieście Moria.

Szczególnie interesujący wydaje mi się sam zamysł kompozycyjny autorki, by na prawach swego rodzaju eseistycznej licentia poetica połączyć końcową partię Lesbos z pozostałymi biograficznymi szkicami, co ciekawie koresponduje z narracyjnymi gestami Tadeusza Sławka z książki U-chodzić - kiedy tytułową kategorię, odnoszącą się do pewnej specyficznej formuły podmiotowości, konturu życia wewnętrznego, uczony odróżnia od kondycji uchodźczej. Tym samym w obu esejach sytuacja uciekinierów szukających azylu przedstawiana jest poza językiem doraźnych problemów, wpisana zostaje w szerokie kulturowe konteksty. Dodatkowo Lis zdaje się, 
wprawdzie nie bezpośrednio, stawiać pytanie o kondycję oraz estetykę i formę narracji eseistycznej wobec zjawiska współczesnych migracji ${ }^{2}$.

\section{3.}

Słowa: „u-chodząc”, „u-chodzić”, „u-chodzący” (oraz pochodne) Sławek konsekwentnie zapisuje małą literą i z dywizem. W ten sposób już na poziomie typografii charakteryzuje postawę kogoś, kto umyka z mocnej tożsamości, stroni od powagi imienia własnego, nie zakotwicza się w świecie za pomocą majuskuły (Sławek 2015, 35) - postawę kogoś, kto od świata odstaje: „wstawiamy dywiz między dwie, jakże nierówne, części wyrazu: u-chodzenie jako niesubordynacja wobec życia, nie jest jego odrzuceniem, lecz przeorientowaniem. Nie wypełniam sobą świata, a ten uwolniony ode mnie zmierza w innym niż zawsze kierunku” (Sławek 2015, 78). W znacznej mierze refleksje Sławka poświęcone są relacjom jednostki ze wspólnotą, „sposobom angażowania się” (Sławek 2015, 132) poza ramami instytucji publicznych, ról i powinności regulujących zasady społecznego funkcjonowania. U-chodzący zachowuje wobec nich dystans, bo wie, że nie zdołają pomieścić rzeczywistości w jej wszystkich przejawach, w nieustannej metamorfozie. Występuje więc również przeciw narracjom, w których pojedynczy los uchodźcy czy uchodźczyni staje się „problemem uchodźców”, rozważanym wyłącznie w kategoriach administracyjnych i ekonomicznych. Zarazem temu doświadczeniu w meandrycznej, rozpisanej na kilkaset fragmentów, narracji autor poświęca tylko parę rozproszonych wzmianek oraz jeden dłuższy, choć zaledwie parustronicowy wywód, wart zacytowania za chwilę niemal in extenso. Równocześnie kwestie przymusowej migracji, zawsze dramatycznej ucieczki z ojczyzny, wprawdzie niewypowiedziane, będą powracać w całej książce, jako szczególny punkt odniesienia.

W dociekaniach skupionych wokół relacji między postawą u-chodzących a kondycją uchodźców Sławek pokazuje, że etymologiczne pokrewieństwo słów może być mylące. Zarazem w kilku erudycyjnych przybliżeniach objaśnia, dlaczego ci drudzy, szczególnie podatni na krzywdę, tak bardzo potrzebują pierwszych - wolnych wewnętrznie i zewnętrznie, zawsze gotowych, wzorem Henry'ego Davida Thoreau, wypowiedzieć obywatelskie posłuszeństwo, czujnie obserwujących funkcjonowanie władzy, organów administracyjnych dość łatwo, choć często niezamierzenie, uruchamiających mechanizmy opresji. W kontekście tych rozważań niezwykle ważny dla uczonego jest fragment poematu, zmarłego w 2017 roku anglojęzycznego noblisty o karaibskich korzeniach, Dereka Walcotta - The Prodigal (opublikowany w 2006 roku), co należałoby przetłumaczyć jako „Marnotrawny”.

\footnotetext{
${ }^{2}$ Z pewnością eseistyka Renaty Lis (także dwie poprzednie książki autorki: Ręka Flauberta oraz W lodach Prowansji. Bunin na wygnaniu) zasługiwałaby na osobne opracowanie w kontekście gatunkowym, w odniesieniu do najnowszych studiów na ten temat. Por. Chmielewska, 2001; Sendyka, 2006; Lisak-Gębala, 2014. Warto tu również przywołać - jako wypowiedź w pewnym stopniu autotematyczną, a na pewno deklaratywną - krytyczną recenzję Renaty Lis (Lis 2017a) poświęconą zredagowanej i opracowanej przez Jana Tomkowskiego antologii Polski esej literacki, wydanej w serii Biblioteki Narodowej.
} 
Kilka wersów wyjętych przez Sławka z utworu staje się soczewką skupiającą obrazy obecne $\mathrm{w}$ imaginarium zbiorowym, obrazy ludzi uprzedmiotawianych - w miejscach, z których uciekają oraz w miejscach, do których docierają i proszą o azyl.

u-chodzić po to, aby przyszłość nie musiała być historią uchodźstwa. Derek Walcott o uchodźcach: „Falowy ruch uchodźców, nie odlot dzikich gęsi, / w wagonach towarowych twarze, nędza, węgliki / oczu, najostrzejsze spojrzenia dzieci, wielkie / toboły taszczone przez most / skrzypią osie (...) / rozmywają się granice, / jak trupy potopione w gliniankach albo / barwna mierzwa jesieni wdeptywana w błoto, / a cyprysowe dymy znaczą Sachsenhausen..." [Walcott Derek, 2008, The Prodigal, Heydel M. (przeł.), w: Mapa Nowego Świata. Wiersze wybrane, Heydel M. (wybór i red.), Kraków, s. 153]. Historia to dzieje uchodźstwa. Takie uchodzenie będące rodzajem ucieczki jest „ludzkie”, co więcej - jest tym, czego znaki odnajdziemy w całej historii człowieka. Dramat uchodźcy polega nie tylko na utracie domu ojczystego, lecz również na tym, że miejsce, do którego się udaje, pokonując liczne, często śmiertelne trudności, daje mu wyraźnie do zrozumienia, że jest w nim niepożądanym przybyszem. W miarę upływu stuleci, jak dowodzi Hans Blumenberg w swym monumentalnym dziele, Odyseusz „nie reprezentuje już nowego zbawienia, a tylko dawną rozpacz" [Blumenberg Hans, 2009, Praca nad mitem, Najdek K., Herer M., Zwoliński Z. (przeł.), Warszawa, s. 75].

u-chodzący okazuje się ratunkiem w dramacie uchodźstwa. Zdaniem Karla Augusta Böttigera, którego przywołuje Blumenberg, ostatnia możliwa w nowoczesnym świecie Odyseja musi się zająć losem tych, których dzieje zmusiły do ucieczki z ojczyzny, a zatem nieodwołalnie musi paść pytanie o nową formułę gościnności dla świata i w świecie.

Wprawdzie pyta cały czas Sławek, co u-chodzący może zrobić dla uchodźcy - to pytanie wręcz niczym refren organizuje jego rozważania - ale jednocześnie odkrywa, że zetknięcie z uciekinierem, poszukującym azylu, może (i powinno) wpłynąć na sposób problematyzowania świata przez ludzi bezpiecznych i wolnych, skłaniając ich do przeformułowania pewnych tradycyjnych wartości europejskich, jak choćby owa wspomniana gościnność.

Na czym polega ratunek, jaki u-chodzący może przynieść uchodźcy? Po pierwsze na tym, że nie będąc nigdy przekonany, że jest „u siebie”, u-chodzący zawsze powstrzyma się przed stygmatyzowaniem kogokolwiek za jego „obcość”. Skoro słowa Ciorana - „Jestem obcy dla policji, dla Boga, dla samego siebie” [Cioran Emil, 2008, Zły demiurg, Kania I. (przeł.), Warszawa, s. 100] dobrze opisują sytuację u-chodzącego, unieważniają one jakiekolwiek podstawy do poczucia wyższości wynikającej z zadomowienia. Po drugie, gościnność u-chodzącego nie bierze się z przeświadczenia o odrębności własnego domu, którego osobność musi zostać potwierdzona po to, aby mógł on zaprosić do siebie i na swoich warunkach gości. Gościnność u-chodzącego nie podlega więc „prawu” gościnności, prawo to bowiem od samego początku zniekształca gościnność, gdyż trzeba niemal ksenofobicznie stale potwierdzać swe racje do posiadania ojczyzny, własnego domu, aby móc kogokolwiek w nim gościć. 
W ostatniej cząstce z przywoływanej sekwencji tematycznej wraca Sławek do obrazów z zacytowanego wcześniej poematu Walcotta, jak pokazuje, obrazów z antropologicznego punktu widzenia niezbywalnych, niezbędnych do zrozumienia mechanizmów historii. U-chodzący potrzebuje mieć je w pamięci niczym przestrogę przed iluzją stwarzaną przez instytucje, zapewniające pozorne poczucie bezpieczeństwa, zwalniające $\mathrm{z}$ odpowiedzialności za funkcjonowanie społecznych relacji, a w istocie zamieniających je w anonimowe struktury, przejmujące kontrolę nad życiem jednostek. Toteż interweniując, pomagając potrzebującym, u-chodzący robi jednocześnie wszystko, by uniknąć kondycji uchodźcy. Dlatego tak duże znaczenie przypisuje do języka, demaskuje zdystansowany żargon biurokratycznych procedur, szuka porozumienia nie z urzędami, nie z władzą, lecz z osobami. A przy tym zawczasu wystrzega się wiary w trwałość porządku świata i własnego w nim miejsca.

U Dereka Walcotta „ruch uchodźców” różni się dramatycznie od „odlotu dzikich gęsi". Gęsi formują szyk i z gracją płyną wysoko w powietrzu; człowiekowi pozostał bydlęcy wagon i „wielkie toboły” przewożone na skrzypiących wozach. Nie można pojąć człowieka bez zjawiska tej dramatycznej migracji. u-chodzenie nawiązuje wprost do ptasiej wędrówki, chce się wydostać z kolein historii. „Cyprysowe dymy Sachsenhausen" są tragicznym znakiem tego, co dzieje się, gdy nie podejmujemy trudu u-chodzenia. Rzecz jest podwójnej natury: ci, którzy zdołali ujść, zachowali życie, migrując z miejsca na miejsce, zmagając się z bezduszną biurokracją (jak ci, których eufemistycznie określa się mianem sans papiers), lawirując między wrogimi mocarstwami (jak w Casablance). Przypomnijmy, co pisze Hannah Arendt o biurokracji jako o formie „rządu, w której zanika personalny element rządzenia" [Arendt Hannah, b.r.w., Polityka jako obietnica, Madej W., Godyń M. (przeł.), Warszawa, s. 108]. Ale u-chodzenie jest inne; znajduje wyraz w czujnej, krytycznej postawie wobec politycznych ustanowień i języka, jaki ustanowienia te narzucają. Tak pojmowane u-chodzić to zwrot nonkonformistyczny pozwalający z jednej strony na zgłoszenie sprzeciwu wobec władzy, z drugiej - pomagający odzyskać język „osobny”, odrębny od dyskursu władzy, język, który moglibyśmy władzy przeciwstawić (Sławek 2015, 41-43).

Swój esej Renata Lis domyka do pewnego stopnia pokrewnym rozpoznaniem: „Uchodzę. Wracam. I znowu uchodzę” (Lis 2017, 193). Ten enigmatyczny wygłos poprzedza szczerym zwierzeniem. Na ostatnich stronach książki autorka wyznaje, jak przeżywa swoją tożsamość prawnuczki i wnuczki uciekinierów ze Wschodu, z Uralu, „obywateli Napowietrznej Rzeczpospolitej Dworców, Wagonów i Tułaczych Tobołów" (Lis 2017, 192), po których dziedziczy ambiwalentny stosunek do miejsca przesiedlenia, do już zawsze „obco-swojej kultury, klimatu i języka” (Lis 2017, 192). I od razu zapewnia: „[w]ciąż nie dość swoja, za mało polska, niekompatybilna. Nie skarżę się, nie napraszam i nie przepraszam - nie jestem stąd w najgłębszym sensie, to wszystko" (Lis 2017, 192). Te wyimki pochodzą z monologu skierowanego do anonimowego Greka, który na ulicy jednego z miast Lesbos 
zapytał autorkę, czy przypadkiem nie jest uchodźczynią. Lis, zaprzeczywszy na głos, odruchowo, naprawdę odpowiedziała mu dopiero w myślach:

I am a refugee, jestem uchodźczynią, choć niedokładnie w tym sensie, który ty miałeś na myśli. Nazywając się tak, nie chcę obrazić tych wszystkich śmiertelnie przerażonych ludzi, którzy wołają z odmętów Morza Śródziemnego, de profundis, i którzy toną w otchłani, patrząc na nieosiągalne wybrzeże Europy. Zwłaszcza że trochę znam to uczucie, znam je, by tak rzec do pewnego momentu, bo kiedy sama się w tym morzu topiłam - wsteczny prąd wciągnął mnie pod wodę i miotał mną jak szczapką, nie mogłam się wynurzyć, żeby zaczerpnąć tchu albo zawołać, wszyscy patrzyli i nikt nie widział, możesz mi wierzyć, naprawdę niewiele brakowało. Więc nie chcę ich obrazić tym porównaniem, bo wiem doskonale, że ich życie i moje nie dają się w tej chwili porównać. Myślę jednak, że tonąć można na wiele sposobów, a uchodźstwo - mimo wszystkich różnic i zastrzeżeń jest stanem nie tylko powszechnym, ale też stopniowalnym, i że naprawdę nikt nie może czuć się bezpieczny. Nawet jeśli w tej chwili niektórym $\mathrm{z}$ nas się wydaje, że ich to nie dotyczy i nigdy dotyczyć nie będzie, to jest to tylko naiwne złudzenie, dziecinne myślenie życzeniowe, bo w pewnej chwili i to nawet bardzo prędko my także możemy się znaleźć w jakimś obozie Moria, specjalnie dla nas zbudowanym, w takich samych białych namiotach przysypanych śniegiem, w których potrujemy się czadem albo w metalowych barakach za drutami - sprowadzeni do tego pierwotnego stanu, z którego, wedle midraszowej mądrości, ulepieni zostali człowiek i świat (Lis 2017, 190-191).

Tym samym eseistka stawia pytanie, czy kondycję uchodźcy można potraktować metaforycznie, czy tego rodzaju zabieg jest stosowny, czy nie zawłaszcza, a przede wszystkim nie relatywizuje nadmiernie doświadczenia ludzi, którzy wciąż giną, próbując dotrzeć do Europy. Jednocześnie szukając wspólnoty z nimi - wykluczonymi, autorka podkreśla akcydentalność ich losu, przypomina, że kategoria uchodźcy nie jest przypisana do określonej grupy etnicznej, jest swoiście przechodnia historycznie, w konsekwencji Lis przeciwstawia się mechanizmom izolowania kogokolwiek przez wiktymizację. Pisze też: „tonąć można na wiele sposobów” (Lis 2017, 191), jakby sygnalizowała, iż w centrum jej zainteresowania w Lesbos znalazły się poniekąd pokrewne doświadczenia kobiet narażonych na ostracyzm ze względu na nienormatywną orientację seksualną.

Ani Lis, ani Sławkowi nie można więc zarzucić niefrasobliwości, bowiem ukazując kondycję i los uchodźców przez analogie oraz konteksty, unikają jednak nadużyć. Nie tyle zresztą rozszerzają nadmiernie zakres znaczeniowy tego doświadczenia, co raczej upominają się o właściwą kategorii wielowymiarowość, którą we współczesnym słowniku (a zwłaszcza uzusie) niesłusznie rezerwuje się dla szczególnej, wręcz granicznej sytuacji ludzi uciekających ze swojego kraju, a w konsekwencji sprowadza się do zazwyczaj negatywnych konotacji, związanych z uprzedzeniami mieszkańców krajów udzielających schronienia oraz ze swego rodzaju „przemocą asymilacji” . Zarazem wyraźnie słychać, jak ciekawie i twórczo różnią się te dwie interpretacje. Sławek afirmuje postawę u-chodzącego, przedstawia ją jako dostępną jedynie aproksymatywnie, rodzaj wciąż podejmowanego zadania; 
Lis zaś twierdzi, że uchodźstwo to doświadczenie uniwersalne, mniej lub bardziej świadomie przeżywane i rozpoznane, jest udziałem każdego człowieka, ma jednak charakter ambiwalentny.

4.

Wiele wskazuje na to, że Lis poleciała na Lesbos, już napisawszy, a zapewne nakreśliwszy, pierwsze trzy części swojej książki poświęcone - przypomnę - pisarkom przywołującym w swojej twórczości postać Safony. Co ciekawe, tylko jedna spośród bohaterek eseju, w dodatku wprowadzona jedynie kontekstowo - Hilda Dolittle - odbyła podobną podróż, pozostałe raczej nie szukały genius loci ojczyzny tak ważnej dla nich artystki. Również Lis nie spodziewała się, że trafi na ślady greckiej poetki, chciała jednak przekonać się, jaką opowieść ma dla niej wyspa Safony (Pisać na głos, 2017) - w czasach starożytnych słynna „wyspa poetów” (Lis 2017, 134) - z jakimi wrażeniami, obrazami wróci z wyprawy, prawdopodobnie celowo zaplanowanej na okres przed sezonem turystycznym.

I odkryła najpierw, że obecnie do największych miejscowych atrakcji zalicza się możliwość obserwowania migrujących ptaków. Notuje więc: „[w] Anglii - gdzie, trzeba dopowiedzieć, fascynacje ornitologiczne nie są wyłącznie domeną specjalistów, podziela je kilka milionów amatorów - przewodników o ptakach Lesbos ukazuje się kilkakrotnie więcej niż zwykłych przewodników" (Lis 2017, 156). Podczas pobytu na wyspie w marcu 2017 roku Lis natknęła się na jedno z takich siedlisk.

Mniej więcej w środku Lesbos, u szczytu Zatoki Kalloni, rozpościerają się (...) słone mokradła - gorzkie sadzawki - do których ciągną migrujące ptaki. W tym roku zdążyły już przylecieć różowe flamingi i czaple: białe oraz siwe. Za pieniądze z Unii Europejskiej ustawiono tu drewniane budki na palach, skąd przez lornetkę można oglądać brodzących w salinach ptasich migrantów, nie wywołując wśród nich popłochu. Flamingi z Kalloni są spokojne i raczej nie śnią im się koszmary takie jak w wierszu Wata Sen flaminga, w końcu nie znajdują się w brzuchu Lewiatana ani na rozkołysanym Śródziemnym Morzu, nie wiedzą nic o istnieniu granic, stoją po prostu na ziemi, i to całą jedną nogą. Tak się przynajmniej wydaje (Lis 2017, 156).

Nawet opisując obóz dla uchodźców, eseistka zauważa ślad obecności ptaków: „[w]ysoko nad bramą, w załomie muru ulepiły swoje gniazda jaskółki - skrzydlaci migranci, którzy przylecą tu z Afryki dopiero za miesiąc" (Lis 2017, 164).

Lesbos okazuje się więc bezpieczną enklawą dla ptaków wędrownych, tym bardziej wyjątkową, że w trakcie corocznej migracji właśnie na południowych krańcach Europy narażone są one na liczne niebezpieczeństwa ze strony ludzi, zabijających tu niespodziewanie dużą liczbę zwierząt chronionych $\mathrm{w}$ innych częściach kontynentu. O zagrożeniach, na jakie natrafiają w tych rejonach, opowiadał Stanisław Łubieński w szkicu zamykającym zbiór Dwanaście srok za ogon: 
W sezonie migracji w krajach Morza Śródziemnego giną tysiące krasek. Zresztą nie tylko ich. Myśliwi nie wyróżniają żadnego gatunku. Umierają miliony ptaków, wśród nich także kraski [w Polsce objęte ochroną - przyp. AJ]. Przygnębiające, że choć na ochronę tego szafirowego skarbu wydajemy niemałe pieniądze, to całą naszą mikroskopijną populację może unicestwić jeden człowiek. I to niekoniecznie człowiek głodny. Wielu strzela raczej dla sportu albo chwały na portalu społecznościowym. Co roku tysiące zdjęć zabitych ptaków trafiają do sieci. I choć proceder prawie wszędzie jest nielegalny, to w niespokojnych krajach Bliskiego Wschodu walka z kłusownictwem nie należy do priorytetów (Łubieński 2016, 177).

Łubieński opisuje zwyczaje polujących na ptaki Egipcjan, którzy „tłumaczą, że nie zabijają gatunków rodzimych, tylko «obce»" (Łubieński 2016, 178) (nie sposób oprzeć się wrażeniu, jak łatwo w tym zdaniu słowo „gatunek” podmienić na przykład na „narodowość”). Podobnie postępują Włosi oraz Libańczycy.

Myśliwi z Libanu, ci bardziej majętni, chętnie podróżują. Późnym latem i jesienią wybierają się na przykład do Rumunii. Tu zabijają między innymi turkawki, przepiórki i małe ptaki śpiewające. All inclusive. Nawet analiza profili myśliwych na portalach społecznościowych pokazuje wyraźnie, że ustalone urzędowo limity odstrzałów są wielokrotnie przekraczane. Autor reportażu The Massacre of Europe's Songbirds szacuje, że spośród pięciu miliardów ptaków, które jesienią lecą do Afryki i w rejon śródziemnomorski, ginie około miliarda. Drapieżniki zabija się za pomocą zatrutej padliny, głośniki z nagraniami wabią drobnicę w sieci i klejowe pułapki. Ptaki siadają na gałęziach pokrytych gęstą mazią, która nie pozwala im odlecieć i najczęściej umierają z wycieczenia w palącym południowym słońcu. $\mathrm{Na}$ przykład na Malcie morderczą miksturę robi się ze śliwek.

W Unii Europejskiej obowiązuje tak zwana dyrektywa ptasia, która nakazuje chronić nie tylko ptaki, ale też ich siedliska. Niestety kraje członkowskie mogą robić od jej zapisów odstępstwa. Za zabicie któregoś z gatunków ptaków jedzonych we francuskich restauracjach w Anglii trafiłoby się do więzienia. Paszkot upolowany w Rumunii musi zostać do Włoch przemycony. Biznesem rządzą zorganizowane gangi - ptaki są pozbawiane głów i częściowo oprawiane, by utrudnić ich identyfikację. Jaka jest skala procederu? Olbrzymia. Dość powiedzieć, że w jednej ciężarówce jadącej z Serbii włoska straż graniczna znalazła sto dwadzieścia tysięcy ciasno spakowanych ptaków.

Na Bałkanach i w Rumunii polują głównie Włosi. Można ich spotkać o każdej porze, w sezonie i poza nim. Włoscy myśliwi mogą wywieźć z Rumunii po sto skowronków na dzień, ale rzeczywiście wywożą ich znacznie więcej. Organizator łowieckich wycieczek pochwalił się autorowi artykułu, że rekordzista ustrzelił w ciągu doby czterysta ptaków. Firma zapewniła mu składane krzesełko, by za bardzo się nie zmęczył. Krzesełko stanęło w sąsiedztwie świeżo zżętego pola, na którym żerowały stada ptaków. Rumuński rząd nieustannie rozluźnia prawo chroniące ptaki, w zeszłym roku wydano na przykład pozwolenie na odstrzał jednej trzeciej populacji skowronka. Wielu myśliwych z Włoch to szefowie firm i banków, słowem - potencjalni inwestorzy, a skowronki są dla nich przynętą (Łubieński 2016, 184-185, podkreśl. AJ).

Powyższy obszerny fragment, odznaczający się pewną dramaturgią, przemyślaną kompozycją, to zaledwie wyimek z „unaoczniających”, niezwykle sugestywnych opisów Łubieńskiego poświęconych losowi migrujących 
ptaków, które stają się ofiarami myśliwych i kłusowników; zebrany przez autora Dwunastu srok za ogon katalog przykładów tego rodzaju czynów jest istotnie zatrważający - wiele mówi o ludzkiej bezmyślności, a jeszcze więcej o pysze i arogancji. Jednocześnie wszystkie (przedwczesne) sądy na temat „barbarzyńskich” praktyk zabijania wyczerpanych wędrówką zwierząt, które w Polsce i w wielu innych krajach objęte są ścisłą ochroną, wszelkie takie głosy, jak najbardziej słuszne, wymagają autorefleksji na temat rodzimych zwyczajów, choćby organizowania niezwykle dochodowych „polowań dewizowych”, więc na temat, by ująć rzecz szerzej, groźnych nawyków relatywizowania kwestii, których nie należy relatywizować.

Zgromadzone przez Łubieńskiego informacje można uznać za przejaw wewnętrznej dezintegracji wspólnoty europejskiej, przykład egoistycznych nadużyć dokonywanych przez poszczególne państwa wbrew przyjętym ustaleniom i kosztem zwierząt, nadużyć analogicznych do tych, do których bezprawnie uciekają się kraje odmawiające, jak Polska, pomocy uchodźcom. Skłaniałabym się jednak ku bardziej radykalnemu ujęciu, nietraktującemu naszkicowanego tu porównania wyłącznie pretekstowo, na zasadzie kwestii drugorzędnej na tle problemów, z jakimi mierzy się współczesny świat. Bowiem narracje o uciekinierach szukających schronienia w Europie, poza doraźnym interwencyjnym i edukacyjnym wymiarem, potrzebują również nieantropocentrycznego i egzystencjalnego otwarcia - wówczas doświadczenie migracji stanie się doświadczeniem na wielu poziomach przeobrażającym wszystkie grupy, których dotyka: przybyszów oraz przyjmujących ich mieszkańców. Szczególnie ci ostatni potrzebują podejrzliwie spojrzeć na swój język - nadmiernie normatywny, zasobny w potencjalnie wyobcowujące formuły, stygmatyzujący również przez zabiegi wzajemnej antagonizacji ofiar, polegające przede wszystkim na stosowaniu animalnych inwektyw (tak charakterystycznych dla wszelkich ksenofobicznych dyskursów). Wszak uchodzące za poniżające, wręcz obraźliwe w wymowie, porównania do zwierząt podtrzymują antropocentryczną hierarchię, w myśl której utrata statusu człowieka skutkuje nie tylko utratą godności, ale również uprzedmiotowieniem i utratą prawa do decydowania o własnym życiu. Co z kolei najdobitniej zaświadcza o podrzędnym miejscu, jakie człowiek przyznaje zwierzętom w swoim świecie. Właśnie między innymi to zjawisko wiąże się z postulatami myślicieli posthumanistycznych, głoszących, iż refleksji w rodzaju tej, jaką uprawiają, nie można ograniczać do wąsko rozumianych studiów ekokrytycznych czy studiów nad zwierzętami, gdyż wrażliwość na pozaludzkie formy istnienia winna przenikać wszelkie obszary świadomości krytycznej, zatem nie tylko rozprawy i wypowiedzi związane bezpośrednio, bo na płaszczyźnie tematycznej, z problemem relacji międzygatunkowych (Wolfe 2013, 125-153). Równie ważna byłaby zmiana językowych przyzwyczajeń, rezygnacja z owych animalnych inwektyw, wyczulenie na nie podobne do wyczulenia na podszyte antysemityzmem sformułowania takie, jak „judzić” itp. 


\section{5.}

„Nie rodzę się, lecz wylęgam” (Sławek 2015, 123) - deklaruje w pewnym momencie Tadeusz Sławek. A w poprzednim zdaniu pisze: „u-chodząc, zmierzam w stronę odkrycia wspólnoty z tym, co nie-ludzkie" (por. Jarzyna 2017, 107-141). Bowiem jedną z kluczowych cech wypracowywanej przez uczonego postawy jest formuła rozszerzonej podmiotowości. Jako że u-chodzić znaczy myśleć w poprzek hierarchii, krytycznie odnosi się on do wizji świata podporządkowanego człowiekowi, zwraca uwagę na relacje międzygatunkowe, zinstrumentalizowane do tego stopnia, że często właściwie niewidzialne, w wielu kluczowych aspektach związanych z przemocą i wyzyskiem wciąż nie dość problematyzowane. Pisze Sławek, że postrzegane w tej perspektywie zwierzęta należą do „reszty” istnienia, która zawsze zostaje, zmarginalizowana, gdy ująć rzeczywistość w jednoznaczne kategorie, „reszty”, która stanowi co najwyżej tło w nadmiernie usystematyzowanej rzeczywistości zagospodarowanej wedle ludzkich potrzeb. Tym bardziej dlatego świadomy swej supremacji człowiek winien próbować się usunąć, świadomie ograniczać swoją dominującą pozycję.

6.

Niemniej, by rzeczywiście wydobyć z obu tych narracji nieantropocentryczną refleksję, najpierw należałoby wprowadzić do nich jedną korektę. Otóż, kiedy Lis, wprawdzie z pewnym wahaniem, stwierdza, że ptaki „nie znają granic", i w ten sposób w domyśle przeciwstawia ich migracje położeniu uchodźców, zaś Sławek odwołuje się do obrazu dzikich gęsi, to powtarzają klisze ze zbiorowego imaginarium, w którym zwierzęta stają się nośnikami przyporządkowanych im mniej lub bardziej arbitralnie znaczeń. Zdaje się jednak, że przejmując z pozoru niewinne i kulturowo zakorzenione porównanie, żadne z obojga autorów nie było świadome, jak dalece problematyczne i pozbawione realnego punktu odniesienia stało się to zestawienie, kiedy ptasia wędrówka nie wiąże się już ze swobodą, lecz z zagrożeniem, znacznie większym niż to wynikające z warunków przyrodniczych, bo spotęgowanym przez arogancję człowieka.

Tym samym dopiero w lekturze kontekstowej - na przecięciu ich esejów ze szkicem Łubieńskiego zmienia się wymowa figury migrujących ptaków. Nie tylko stają się one odtąd raczej figurami losu uchodźców z narażeniem życia przybywających do Europy, nie zaś ludzi wolnych, przede wszystkim jednak okazuje się, że nie można przedstawiać ich wyłącznie jako figur dyskursu, że są podmiotami, które potrzebują troski, ale nie troski okazywanej z wyższościowej perspektywy zarządców życia, urzędniczo kalkulujących na przykład, ile zwierząt w danym roku mogą zastrzelić myśliwi, by w kolejnych latach populacja gatunku się nie zmniejszyła. Wszak opieka nie może opierać się na tego rodzaju wyliczeniach (niepokojąco kojarzących się z ustalaniem tzw. „kwot” uchodźców, jakie 
przyjąć miały poszczególne kraje Unii Europejskiej), nie może polegać na uśmiercaniu części spośród podopiecznych.

Pisząc za Stanisławem Łubieńskim o losie ptaków, których śmierć z rąk myśliwych nie jest morderstwem, jest co najwyżej wykroczeniem, nie myślę jedynie o nich. Myślę o szerszej antroponormatywnej logice oraz rządzącej nią binarnej i wartościującej opozycji ludzie/zwierzęta, gdzie zwierzę - by posłużyć się formułą Joanny Tokarskiej-Bakir - to „prototyp ofiary” (Tokarska-Bakir 2015, 70). Bowiem ustanawia kategorię, wiążącą się z procesem animalizacji, kategorię elastyczną, która wielokrotnie już obejmowała i wciąż obejmuje określone grupy ludzi, posługiwanie się nią bezpośrednio skutkuje przyzwoleniem na dyskryminację istot należących do gatunków innych niż człowiek. Znamienne, że w pewnym momencie charakteryzując obóz dla uchodźców, Lis (odruchowo?) sięga po język dozoru sanitarnego czy raczej weterynaryjnego, „język kontroli epidemii” (Tokarska-Bakir 2015, 76): „obóz pochłania biomasę i usuwa ją z pola widzenia. Wygląda jak miejsce operacji na niebezpiecznym organizmie albo zakład przetwórstwa o zaostrzonym rygorze" (Lis 2017, 164). W hodowlach przemysłowych, na fermach - z reguły swoiście niewidocznych, nierozpoznawanych na obrzeżach miast - zwierzęta uznaje się za „żywą materię”, półprodukt, toteż zgodnie z procedurami masowo zabija się je także, gdy pojawi się podejrzenie, iż mogą być nosicielami śmiercionośnych wirusów. Zatem ten sam mechanizm rządzi procedurami postępowania wobec zwierząt i ludzi uznawanych $\mathrm{z}$ jakiegoś powodu za niebezpiecznych. Przeciwdziałanie rzekomemu zagrożeniu $\mathrm{z}$ ich strony $\mathrm{w}$ istocie wiąże się $\mathrm{z}$ koniecznością wprowadzenia już zawczasu stanu wyjątkowego, któremu wedle deklaracji odpowiednich instytucji właśnie w ten sposób się zapobiega. Skutkuje to symboliczną i również przynajmniej częściowo fizyczną, jak na Lesbos, izolacją danej grupy. Co z kolei ponownie potwierdza diagnozę stawianą już wielokrotnie przez krytyków paradygmatu antropocentrycznego (między innymi Dominicka LaCaprę i Joannę Tokarską-Bakir), słusznie wykazujących, że dopiero dostrzeżenie, iż jednym z najbardziej charakterystycznych przejawów dyskryminacji jest traktowanie jej ofiar w sposób, w jaki zwykle traktuje się zwierzęta, pozwala rozpoznać skalę okrucieństwa wpisanego w codzienne, powszechnie akceptowane praktyki stosowane wobec tych ostatnich. W zasadzie nie inaczej rysuje się warstwa leksykalna w cytowanym fragmencie eseju Sławka, sięgając po wiersz Walcotta, myśliciel przypomniał obrazy bydlęcych wagonów, w których przewożono przesiedleńców, a przede wszystkim skazanych na Zagładę, i pisał dalej, nie zatrzymując się przy przymiotniku „bydlęcy”, że doświadczenie uchodźstwa, ucieczki jest ludzkie, co przecież łatwo podważyć. Wystarczy choćby pomyśleć o zwierzętach pozbawianych swoich siedlisk - na przykład w wyniku wycinki lasów.

W obu esejach daje się wysłyszeć, użyty prawdopodobnie odruchowo, normatywny język zleksykalizowanej różnicy antropocentrycznej, przejawiający się przyswojeniem nacechowanej pejoratywnie animalizacji, która 
wynika z powszechnie przyjętego postrzegania przedstawicieli innych gatunków jako istot gorszych od ludzi, toteż zrównanie z nimi jest dla tych ostatnich uwłaczające. Ów język, odsłaniając niesłusznie wypieraną, swoiście izolowaną od podejmowanych przez autorów kwestii, problematykę analogii między stosunkiem do uchodźców i do zwierząt - stosunkiem co najmniej paternalistycznym - wskazuje konteksty warte, a wręcz wymagające przepracowania, stematyzowanej refleksji. Stawia w zasadzie retoryczne już pytanie o to, czy można przeciwstawiać się ksenofobii, nie przeciwstawiając się postawie antropocentrycznej. Co zdaje się istotne zwłaszcza w związku z ideą u-chodzenia, formułą podmiotowości otwartej, międzygatunkowej wspólnoty, integrującej pewne obszary doświadczenia ludzi i zwierząt, wyrzekającej się hierarchicznych relacji między nimi.

7.

Obozowi dla uchodźców Lis poświęca kilkanaście, może w sumie dwadzieścia stron, czyli mniej więcej dziesięć procent objętości książki. To najpierw pobieżny i dlatego - paradoksalnie - uczciwy opis warunków życia, obserwowanych z zewnątrz, z perspektywy osoby, która nie posiadała odpowiedniej przepustki, upoważniającej do wejścia na zamknięty i strzeżony teren. Dlatego autorka, by pozostać wiarygodną, nie przypisywać sobie doświadczenia i wiedzy, których nie mogła posiąść, obszernie relacjonuje swoją rozmowę z polską wolontariuszką Jowitą, pracującą jako tłumaczka.

W Morii mieszczą się w zasadzie dwa obozy. Jeden z nich jest namiotowy - prowizoryczny i niedogrzany, utworzony z inicjatywy uchodźców, którzy próbują $\mathrm{w}$ ten sposób żyć na własnych zasadach. Wchodzi się do niego przez bramę z tęczowym napisem WELCOME, a ogrodzenie ma raczej charakter symboliczny, mieści się tam kino na świeżym powietrzu i sklep. Po drugiej stronie drogi znajduje się obóz właściwy - kontenerowy, otoczony wieżami strażniczymi, murem i zasiekami z drutu kolczastego, gdzie muszą się zarejestrować wszyscy przybyli na wyspę.

Miejsce to wygląda jak obóz koncentracyjny i jeśli chce się pozostać uczciwym, nie można uniknąć tego skojarzenia, podobnie jak refleksji, że koncentracja zwykle poprzedza eliminację. (...) Camp Moria is a prison - napisało o miejscu swego pobytu dziecko uchodźców, którego rysunek oglądam w sieci. Dziecka nie wolno nie słyszeć ani mu nie wierzyć (Lis 2017, 163).

Może zatem pierwszy to obóz uchodźców, a drugi - obóz dla uchodźców?

Lis przypomina, że od czasu podpisania umowy między Unią Europejską a Turcją liczba uciekinierów docierających na Lesbos znacznie spadła, bo większość z nich nie miałaby szansy na azyl. W marcu 2017 roku było ich około ośmiu tysięcy, wcześniej - nawet pół miliona osób. W najgorszej sytuacji są mężczyźni, podejrzewani o terroryzm, nikt też nie chce wierzyć tym, którzy deklarują, że jako homoseksualiści ratują się przed prześladowaniami. Lis otwarcie zastanawia się, czy rzeczywiście konieczne są

Polonistyka. Innowacje

Numer 6, 2017 
skrajnie restrykcyjne procedury, które sprawiają, że „nadzieję na pomyślny obrót sprawy mogą mieć tylko bezdyskusyjne ofiary konfliktów zbrojnych lub osoby szczególnie bezbronne i narażone na niebezpieczeństwo (...), na przykład Syryjczycy, kobiety w ciąży, ludzie torturowani lub ranni” (Lis 2017, 168), a wszelkie wątpliwości rozpatruje się na niekorzyść uchodźców. Czy wdrażanie takich przepisów nie jest kolejnym przejawem wyższości Europejczyków, spadkobierców Kurtza z Jądra ciemności Conrada, przed którymi znowu otwiera się „możliwość bezkarnego udręczania innych”? (Lis 2017, 171).

Zapiski Lis z oczywistych względów nie mogą być wyczerpujące. I jako takie nie mogą też szczególnie różnić się od innych podobnych relacji donoszących o dramatycznym losie uciekinierów przybywających do Europy, bezdusznej administracji i ludziach, którzy w ramach niedoskonałego systemu (bądź poza nim) próbują pomagać w nieuwłaczający sposób potrzebującym. Niemniej w tym krótkim fragmencie autorka nie tylko zreferowała sytuację w obozie, przypomniała też, że pojęcie azylu w starożytności miało wymiar religijny, a przede wszystkim zdystansowała się do dominującej narracji podtrzymującej wizję „stanu wyjątkowego”:

Media kochają frazesy, więc na okrągło posługują się określeniem „kryzys emigracyjny", ale to przecież nie jest żaden kryzys, bo kryzys to chwilowe załamanie równowagi, intensywne przesilenie, po którym sytuacja znowu staje się stabilna. Tymczasem te masowe migracje, które w ostatnim czasie zaczęliśmy zauważać, choć trwają od dawna, najprawdopodobniej nie skończą się za naszego życia, ponieważ nie wygasną ich przyczyny. Migracje nie miną i nie da się ich przeczekać, dlatego mylą się ci, którzy próbują uchylać się od współodpowiedzialności za los świata i wszystkich jego mieszkańców. To gigantyczny proces podobny do wielkiej wędrówki ludów, który będzie stopniowo zmieniał nasze życie, aż w końcu zmieni je nie do poznania. (...) Koło Przemian na naszych oczach nabrało rozpędu i wszystko wskazuje na to, że stara forma świata - ta, którą zaczęliśmy uważać za wieczną, ponieważ do niej przywykliśmy - musi wkrótce ulec skruszeniu, ustępując miejsca formie nowej, na razie jeszcze nieznanej. To naturalna kolej rzeczy i jednocześnie wyzwanie, przed którym stanęła cała Europa. Wyzwanie przede wszystkim etyczne, ponieważ wkładanie kija w szprychy Koła Przemian zarówno poprzez pozostawienie uciekinierów z Syrii, Konga czy Sudanu własnemu losowi jak i poprzez opłacanie niedemokratycznych państw graniczących z Unią Europejską, takich jak Turcja czy Libia, aby zatrzymywały ich u siebie, gdzie nie przysługują im prawa uznawane w Europie za minimalne, w praktyce oznacza przykładanie ręki do ich śmierci lub krzywdy (Lis 2017, 167-168).

Oto Lis bardzo wyraźnie podkreśla, iż błędne w krytykowanych przez nią przekazach o chwilowym kryzysie jest założenie, że współczesne migracje nie zmienią, nie naruszą europejskiej tożsamości, że uporawszy się z nimi (choć nikt nie mówi jak i kiedy), ocalimy rzekomo odwieczne status quo. Tymczasem my albo niektórzy spośród nas, szczególnie przywiązani do nadwątlonej już, poróżnionej, ale wciąż homogenicznej wspólnoty, ocalamy raczej iluzję, zasłaniającą prawdę, iż kultury oraz cywilizacje opierają 
się na zerwaniach i ponownych nawiązaniach. Autorka Lesbos nie jest więc orędowniczką przymusowej asymilacji, bliższe jest jej odwrotne nastawienie, polegające na czerpaniu z tego, co przynoszą przybysze, niż arbitralnym deprecjonowaniu i odrzucaniu ich rodzimych tradycji oraz wizji świata.

Również formułowana przez Sławka postawa swoiście odpowiada na wyzwanie integracji, która nie byłaby jednostronna: chodzenie - pisze uczony - „to sposób bycia polegający na braniu udziału w świecie” (Sławek $2015,25)$. Dlatego u-chodzący „nie zagrzewa miejsca” (Sławek 2015, 53), nie tylko współuczestniczy w przemianach swojej społeczności, ale i do nich dąży, a zarazem wyrzeka się potrzeby panowania nad tym procesem. Co znaczy, że nie przystaje na gotowe, zamknięte obrazy rzeczywistości, rezygnuje z ostatecznych ustaleń i pewników (Sławek 2015, 27), także z możliwości sprawowania władzy czy kontroli. Wypatruje nowych form organizacji życia, świadomy, że zawsze będą one przechodnie (Sławek 2015, 30).

W podobnym duchu Lis chce interpretować nazwę miasta (i obozu dla uchodźców) - Moria, eseistka przypomina wyprowadzoną z tradycji żydowskiej etymologię toponimu, jest „zalążkiem świata” (Lis 2017, 161). To ze Wzgórza Moria „świat rozwinął się do swojej obecnej postaci i stąd pochodziła glina, z której Bóg ulepił Adama" (Lis 2017, 161). Tym samym autorka niejako zastępuję narrację katastroficzną, narrację końca, narracją nowego początku. Trudno jej tylko zaakceptować, że naznaczonego bólem i poniżeniem, których przynajmniej w pewnym stopniu można by uniknąć.

8.

Trzeba wreszcie zapytać, czy - choćby w domyśle - Lis buduje paralelę między kondycją bohaterek Lesbos a losem uchodźców. Wówczas okazuje się, że sens zestawienia, jakie autorka konstruuje, opiera się na nieco innych podstawach, i bierze z przesłanek literackich, wręcz warsztatowych, z poszukiwań dla opisu obu doświadczeń w pewnym stopniu podobnego języka wykraczającego poza rejestr publicystycznych doniesień.

To znamienne, że swojej książki eseistka nie zatytułowała „Safona”, tym bardziej, że w któryś momencie pisze: „nie można wykluczyć, że Safona istnieje tylko poprzez inne kobiety podejmujące jej pieśń. Nie można wykluczyć, że Safo płynie wyłącznie w żywym nurcie swojej pieśni" (Lis 2017, 117). Zresztą, co znamienne w kontekście przytoczonych słów, Lis nie próbuje stworzyć opowieści biograficznej o samej Safonie ${ }^{3}$. Zdaje się, że również dlatego zamiast narzucającego się tytułu pochodzącego od imienia starożytnej poetki, na okładce pojawia się jej wizerunek - najstarszy z istniejących, przedstawiony na czarnofigurowej wazie z VI w. p. n. e., należącej do kolekcji Czartoryskich - co na poziomie graficznym ciekawie

${ }^{3}$ Trzeba jednocześnie odnotować, że Renata Lis odsyła do opracowań na temat Safony, zwłaszcza do książki Karola Zielińskiego pt. Słońce $w$ rozpaczy. Liryka miłosna Safony $w$ aspekcie oralności. W tym kontekście warta uwagi jest również praca Stanisława Stabryły, Spiewaj mi Muzo. Cztery opowieści o poetach greckich. 
kontrastuje z umieszonym wyżej słowem Lesbos, zapisanym literami utrzymanymi w "tęczowych" barwach, wprost wskazującymi na solidarność z emancypacyjnymi postulatami środowisk LGBT. To zresztą szczególny gest, bo w samym eseju autorka raczej zdradza sceptycyzm wobec literatury zaangażowanej, określającej się jako „gejowska” czy „lesbijska”. Zatem ta wyspa, swoiście sproblematyzowana już na okładce, okazuje się kolejną bohaterką książki, jest rozmaicie metaforyzowana, jawi się jako swego rodzaju przestrzeń wewnętrzna do odnalezienia w sobie - kobiecie (niekoniecznie lesbijce), uchodźczyni, uchodźcy. „Lesbos - ostatnie miejsce, gdzie «kobiety rosną jeszcze dziko». Jaki cudowny obraz" (Lis 2017, 134) - notuje Lis na marginesie prozy Winterson, mając chyba na myśli pewien stan skupienia wyobraźni, poczucie - jak pokazuje stopniowalne - wolności twórczej autorek, o których opowiada.

Warto spróbować przeczytać poświęcone im pierwsze trzy części książki w kontekście relacji z obozu w mieście Moria, by dostrzec owo przęsło łączące oba tematy. Tryb szczególnie snutej opowieści, w ramach której tożsamość seksualna czy doświadczenie bezdomności, bezpaństwowości, choć rzutuje na całej życie jednostki, nie jest wytrychem do jej losu. Bohaterki eseju uchodziły (i u-chodziły) z życiem, próbując wymknąć z patriarchalnych instytucji, z tak zwanych kobiecych ról - instytucji małżeństwa, instytucji literatury, gdzie miały zajmować jedynie poślednie miejsce, w cieniu wybitnych mężów lub ewentualnie jako autorki tekstów minorum gentium, zwykle tak zwanej popularnej, rozrywkowej prozy. Dwie z nich - Sofia Parnok i Anna Kowalska - były nawet zamężne, co nie przeszkadzało im jednocześnie kochać kobiet. O ile w przypadku pierwszej związek z mężczyzną okazał się epizodem i pomyłką, o tyle druga przez wiele lat pozostawała żoną - chyba niekoniecznie z przymusu, uważała tę relację za ważną, choć częściowo zniewalającą, oceniała ją wyraźnie ambiwalentnie.

Kowalska jest jedyną polską pisarką, która w krótkiej powieści zatytułowanej Safona, wprost podjęła temat greckiej poetki. Lis - eseistka-biografka zawsze wyrozumiała wobec kolei czyjegoś losu, ale zarazem czytelniczka nie znająca literackich kompromisów - twierdzi, że w tej prozie autorka poniosła porażkę, „straciła jedyną w swoim rodzaju szansę, jaką dawał jej temat: mogła przecież stworzyć w Safonie nowy język miłosny, którego w polszczyźnie do dziś brakuje, mogła dokonać przekroczenia, o które saficki temat wręcz wołał i które leżało przecież w jej zasięgu" (Lis 2017, 98). Dalej Lis docieka, z jakiego powodu dzieło, nad którym pisarka pracowała kilkanaście lat, okazało się klęską. Sugeruje, że odbija się w nim klęska związku z Marią Dąbrowską, gorycz wywołana niemożliwością stworzenia prawdziwie partnerskich relacji z ukochaną, pewną przewagi swojego talentu i wymagającą od Kowalskiej, by ta poświęciła własne aspiracje, weszła rolę „żony wielkiego pisarza” - „wielbicielki i podpory” (Lis 2017, 84), pani domu. Chyba dlatego ostatecznie jej Safona, nosząca rysy autorki Nocy i dni, okazuje się postacią antypatyczną, skompromitowaną w dodatku 
przez patriarchalny fantazmat - to prawdopodobnie również skutek ulegania obyczajowym uprzedzeniom. Tego rodzaju zahamowania i lęki sprawiły, że Kowalska wycofała się z pierwotnych zamiarów, zakwestionowała nawet rzeczywisty charakter stosunków swojej bohaterki z kobietami (Lis 2017, 97).

Podobnego relatywizmu Lis nie znajduje w twórczości dwóch pozostałych zajmujących ją pisarek. Warszawska eseistka jest wyraźnie zafascynowana dziełem Sofii Parnok, w Polsce prawie nieznanej rosyjskiej poetki Srebrnego Wieku, która żyła między innymi w związku z Maryną Cwietajewą. Jej wiersze potrafią być zapisem miłosnych uniesień, bez pruderii mówią o nich pełnogłosem. Za Lesbos przywołuję jedną z badaczek tej poezji: „własne lesbijskie skłonności [Parnok - przyp. AJ] uważała za całkowicie naturalne; związki z kobietami zarówno intymne, jak i pozbawione erotycznego zabarwienia stanowiły osnowę jej twórczego i ostatecznym rozrachunku duchowego istnienia" (Lis 2017, 32). Z tym ujęciem zgodziłaby się zapewne Winterson. Brytyjska pisarka, autorka dwóch narracji o Safonie (Poetyka seksu oraz Sztuka i kłamstwa), przeciwstawia się swoistej instytucjonalizacji literatury homoseksualnej (i szerzej mniejszościowej), procesowi zmierzającemu do - jak twierdzi - zawierania wyobraźniowych kompromisów na rzecz nieledwie publicystycznej wyrazistości przekazu. Najbardziej lapidarna formuła jej pisarstwa to wedle Lis: „Więcej, nie mniej” (Lis 2017, 120). Bo Winterson przekonuje, że wprawdzie obyczajowy realizm nie jest niezbędny, ale „[w]iadomo - to, co nie zostało nazwane, nie do końca istnieje i choć jest ciałem, to nie ma ciała, bo ciałem staje się słowo" (Lis 2017, 131).

Wszystkie bohaterki Lesbos jako kobiety, w dodatku lesbijki, musiały mierzyć się z wykluczeniami, kompozycja eseju sugeruje, że z wykluczeniami podobnymi do tych, dotykających dziś uchodźców. Wszystkie one przypomnę określenie autorki - „tonęły”, kiedy internalizowały społeczne uprzedzenia, kiedy doświadczały napiętnowania. Z tym większą determinacją swojego miejsca szukały w literaturze, przekonane, że pisząc, mają szansę przeciwstawić się dyscyplinującemu je heteronormatywnemu językowi. I podobnie Lis zwraca uwagę na brak narracji o szukających azylu uciekinierach, które jednocześnie nie zamykałyby ich w językowych kliszach, nawet tych związanych z pomocą humanitarną, gdyż autorka eseju wie, że przynoszą oni szersze historie, bardziej skomplikowane, przede wszystkim pojedyncze, warte włączenia w europejską tożsamość.

Okruchy pieśni Safony, która sama była niepiśmienna, przetrwały w późniejszych zapisach, także wplecione w utwory zafascynowanych nią poetów. Ślady podobnych zabiegów Lis znajduje w twórczości swoich bohaterek, do podobnych działań sama czuje się zaproszona i zaprasza. Bowiem tworzy opowieść w różnych wymiarach inkluzyjną. Toteż zarówno o refleksach Safo w literaturze, o poszukiwaniach języka wyrażającego miłość między kobietami, więc o kondycji lesbijek, jak i o sytuacji współczesnych uchodźców próbuje mówić równolegle, z pełną świadomością, jak kontrowersyjne lub nawet niestosowne może wydawać się to zestawienie. $\mathrm{W}$ obu przypadkach 
autorka dopomina się o wolność eseistycznej narracji, narracji, której sednem jest właśnie intelektualna komplikacja, wskazująca także na nieoczywiste, nie zawsze uchodzące za poprawne, skojarzenia, narracja pozwalająca wypracować nowy język i kategorie interpretacyjne. Toteż ostatecznie Lis nie podporządkowuje swojego głosu porządkowi dyskursu, nie zważa i nie godzi się na zawężające konteksty, w jakie zwykło się wpisywać zajmujące ją zagadnienia, kiedy sprowadza się je do bieżących problemów.

Jako niepoprawna eseistka zdaje się powtarzać, że stawką są słowo i forma, które będą przenosiły idee oraz doświadczenia, będą włączały je w szersze, bardziej uniwersalne tło, nie odbierając im zarazem swoistości. Pytanie o to, jak mówić, jak opowiadać, okazuje się płaszczyzną, na której w Lesbos spotykają się pod różnymi względami graniczne (i tragiczne), więc umiarkowanie porównywalne, kondycje bohaterek i bohaterów, uchodzących i uchodźców.

\section{9.}

Powtórzę na koniec za Tadeuszem Sławkiem: „u-chodzić to akceptować problematyczność świata” (Sławek 2015, 145). To, jak Renata Lis w rozmowie z Anną Marchewką, marzyć o agorze (Pisać na głos, 2017) - przestrzeni, najchętniej przestrzeni literatury (sztuki), w ramach której każdy głos: kobiety (niezależnie od orientacji seksualnej), uchodźcy, homo- i heteroseksualnego mężczyzny oraz - dodam, pamiętając, że głos, by był zrozumiały, nie musi wiązać się z ludzkimi sposobami artykulacji - zwierzęcia, znaczy tyle samo. Liczy się fakt, że przekazując indywidualne doświadczenie, formuje je w taki sposób, by ów inny punkt widzenia znalazł się w zasięgu wyobraźni odbiorcy uczestniczącego w „ekumenicznej wspólnocie fikcji” (Lis 2017, 131), z której, podkreśla eseistka, „niezależnie od tematu, płci autora i bohaterów korzyści mogą odnieść wszyscy” (Lis 2017, 131), czytelnicy identyfikujący się z odmiennymi perspektywami.

Lesbos, metaforyzowana przez Lis, byłaby zamiast Utopii, byłaby ideą u-topistyczną - w myśl konceptu Sławka, odróżniającego utopistyczność od utopijności. Ta pierwsza „odnosi się do koniecznego uprawiania mądrego życia i roztropnej polityki myślenia w szerokich horyzontach raczej niż w kategoriach doraźnego administrowania lub prognozowania idealnych rozwiązań" (Sławek 2015, 54). Czytam w Lesbos, jak owa idea może być realizowana w materii literackiej, otóż jednym z darów Safony dla zbiorowej wyobraźni było swoiste przewartościowanie ideału piękna. Przed nią „za najpiękniejsze w Grecji uważano wojska w bitewnym szyku oraz flotę, to one roztaczały wokół siebie boski blask. Safo przeniosła tę właściwość na naszych ukochanych - kobiety i mężczyzn - używając do wyrażenia miłosnego zachwytu tych samych epitetów oznaczających blask i harmonię ruchów" (Lis 2017, 139). Miłość wyparła przemoc. 
Tak rysuje się projekt „Lesbos” dla współczesnej wyspy Lesbos - byłby to może przede wszystkim projekt bezwarunkowego azylu udzielanego wszystkim potrzebującym.

\section{Bibliografia}

Chmielewska Katarzyna, 2001, Jak możliwa jest poetyka (eseju)?, „Teksty Drugie", nr 3/4.

Jarzyna Anita, 2017, Wprowadzenie do post-koiné: nieantropocentryczne języki poezji, „Poznańskie Studia Polonistyczne. Seria Literacka”, nr 30.

Kuczyńska-Koschany Katarzyna, 2006, Powstawanka (fragmenty), „Topos”, nr 5.

Lis Renata, 2017a, Esej i kwanty, „dwutygodnik.com”, nr 11 (224), http://www. dwutygodnik.com/artykul/7480-esej-i-kwanty.html (dostęp 29.11.2017).

Lis Renata, 2017, Lesbos, Warszawa.

Lis Renata 2011, Ręka Flauberta, Warszawa.

Lis Renata, 2015, W lodach Prowansji. Bunin na wygnaniu, Warszawa.

Lisak-Gębala Dobrawa, 2014, Ultraliteratura. O strategiach transmedialnych i poszukiwaniu pozawerbalnego we współczesnej literaturze polskiej, Kraków.

Łubieński Stanisław, 2016, Dwanaście srok za ogon, Wołowiec.

Pisać na głos. Rozmowa z Renata Lis, 2017, „dwutygodnik.com”, nr 9 (220), http://www.dwutygodnik.com/artykul/7346-pisac-na-glos.html (dostęp 7.10.2017).

Tomkowski Jan (oprac.), 2017, Polski esej literacki, Wrocław.

Sendyka Roma, 2006, Nowoczesny esej. Studium historycznej świadomości gatunku, Kraków.

Sławek Tadeusz, 2015, U-chodzić, Katowice.

Stabryła Stanisław, 1986, Śpiewaj mi Muzo. Cztery opowieści o poetach greckich, Katowice.

Tokarska-Bakir Joanna, 2015, Książka wyjścia, „Poznańskie Studia Polonistyczne. Seria Literacka", nr 25 (45).

Wolfe Cary, 2013, Co to jest posthumanizm?, Krasuska K. (przeł.), „Teksty Drugie” 2013.

Zieliński Karol, 2006, Słońce $w$ rozpaczy. Liryka miłosna Safony $w$ aspekcie oralności, Wrocław.

\section{O Autorce:}

Anita Jarzyna - doktor, badaczka literatury, głównie poezji XX-wiecznej, interpretatorka. W obszarze jej zainteresowań znajdują się studia nad zwierzętami oraz studia nad Zagładą. Autorka książek „Pójście za Norwidem” (w polskiej poezji współczesnej) (2013) oraz Imaginauci. Pismo wyobraźni $w$ poezji Bolesława Leśmiana, Józefa Czechowicza, Krzysztofa Kamila 
Baczyńskiego, Tadeusza Nowaka (2017); współredaktorka i redaktorka kilku numerów tematycznych czasopism („Poznańskie Studia Polonistyczne”, „Polonistyka”, „Tekstualia”) oraz tomów zbiorowych, w tym T. Nowak, Spowiedź wyobraźni (szkice i rozmowy) (2014). Publikowała m.in. w czasopismach „Colloquia Litteraria”, „Slavia Occidentalis”, „Przestrzenie Teorii”, „Poznańskie Studia Polonistyczne”, „Czas Kultury”, „Konteksty. Polska Sztuka Ludowa" oraz w monografiach zbiorowych. Stypendystka m.in. Funduszu im. Rodziny Kulczyków, Ministerstwa Nauki, Funduszu im. Profesora Władysława Kuraszkiewicza; wyróżniona Medalem Młodej Sztuki w dziedzinie literatura (2015). Kontakt: anitajarzyna@gmail.com 
